\title{
Persoonia hindii (Proteaceae), a new species from the Newnes Plateau, New South Wales
}

\author{
Peter H. Weston and L.A.S. Johnson ${ }^{\dagger}$
}

\begin{abstract}
Weston, Peter H. and Johnson, L.A.S. (National Herbarium of New South Wales, Royal Botanic Gardens, Sydney, N.S.W. 2000, Australia) 1996. Persoonia hindii (Proteaceae), a new species from the Newnes Plateau, New South Wales. Telopea 7(3): 199-203. Persoonia hindii P.H. Weston \& L.A.S. Johnson, a new species from the Newnes Plateau in the Blue Mountains, New South Wales is described and distinguished from its closest relatives. The keys to Persoonia that have been published recently in the Flora of New South Wales and Flora of Australia are amended to include this species.
\end{abstract}

\section{Introduction}

In 1989 Peter Hind collected a specimen of an unusual Persoonia on the Newnes Plateau, in the Blue Mountains, near Lithgow, New South Wales. Subsequent fieldwork by Hind and by one of us (PHW), showed that this specimen represented a rare, unnamed species, which had not been collected before 1989 . We describe it below, using the descriptive terminology discussed by Weston (1994).

\section{Description}

Persoonia hindii P.H. Weston E L.A.S. Johnson, sp. nov.

Frutex erectus vel patulus. Pili $0.3-0.8 \mathrm{~mm}$ longi, adpressi vel antrorse patentes. Folia linearia oblonga, acuminata, (0.3-)1.5-2.7 cm longa, (0.5-)1.0-2.0 mm lata, succulenta, semiteria ubi viva, profunde concava ubi siccata. Inflorescentiae auxotelicae. Alabastra in sectione transversali quadrata. Flores regulares. Pedicelli $2.5-5 \mathrm{~mm}$ longi, moderate pubescentes. Pagina abaxialis tepalorum glabra. Antherae sine appendice. Ovarium glabrum. Ovulum unicum.

Holotype: New South Wales: Central Tablelands: Old Bells Line of Road, $0.1 \mathrm{~km}$ E of Paddys Creek, Newnes State Forest, 33²5'41"S 150²'24"E, P.H. Weston 1948 E D.C. Godden, 24 Jan 1996 (NSW). Isotypes: AD, BRI, CANB, HO, K, MEL, MO, NSW, RSA.

Erect to spreading, multistemmed, suckering shrub, with extensive, linear, stolon-like rhizomes, which lie about $5 \mathrm{~cm}$ below the soil surface, and from which aerial shoots arise at irregular intervals, $0.3-1.0 \mathrm{~m}$ high; bark smooth, grey, present only on substantially woody stems. Hairs $0.3-0.8 \mathrm{~mm}$ long, greyish, antrorsely appressed to antorsely spreading. Immature stems moderately hairy, mostly dull red when fresh; internodes 0-6 mm long. Leaves alternate, linear-oblong, acuminate, (0.3-) $1.5-2.7 \mathrm{~cm}$ long, (0.5-)1.0-2.0 mm wide, succulent, approximately semi-circular in cross-section when fresh, the flat to slightly concave surface being adaxial, rigid and deeply concave when dried, erect but strongly recurved at the base, the lamina spreading and usually 
slightly incurved, sometimes recurved at the tip, \pm laterally symmetrical, not twisted, sometimes pungent when dried, dull brownish green to mid-green when fresh, greygreen to brown when dried, slightly paler beneath, sparsely hairy when immature, retaining a few hairs towards the base but otherwise glabrescent when mature, smooth; venation obscure. Inflorescences growing from terminal or lateral buds, auxotelic, 1-13-flowered; rachis 0-2.0 cm long; flowers subtended by scale leaves and/or reduced leaves at the base of the inflorescence and by full-sized leaves more distally. Pedicels $2.5-5 \mathrm{~mm}$ long, spreading to suberect, moderately hairy, dull red when living. Perianth actinomorphic, the tepals 12-15 $\mathrm{mm}$ long, caudate, strongly keeled along the abaxial midrib so that the buds appear square in cross-section, glabrous on the abaxial surface, deep yellow. Anthers lacking appendages, held close to one another and to the gynoecium at their bases but recurved at the tips, deep yellow; loculi 5.5-7.5 mm long. Gynoecium straight, 9-13 mm long; ovary glabrous; ovule 1. Drupes dull green; pyrene broad-obovoid, 8-9.5 mm long, 5.5-6 mm wide. Seed 1; cotyledons not known. (Fig. 1).

Derivation of epithet: named after Mr Peter Hind, who first collected this species.

Flowering period: January to March, possibly with sporadic flowering in other months.

Habitat: 'Newnes Plateau Woodland' (Benson \& Keith 1990), dry sclerophyll forests and woodlands dominated by a variety of eucalypts, including Eucalyptus sieberi, E. radiata, E. dives, E. pauciflora, E. oreades and E. gullickii, on soils derived from Narrabeen Sandstone, from 1130 to $1170 \mathrm{~m}$ altitude.

Distribution: known from several sites on Newnes Plateau, north of Lithgow, New South Wales (Figs. 2-3).
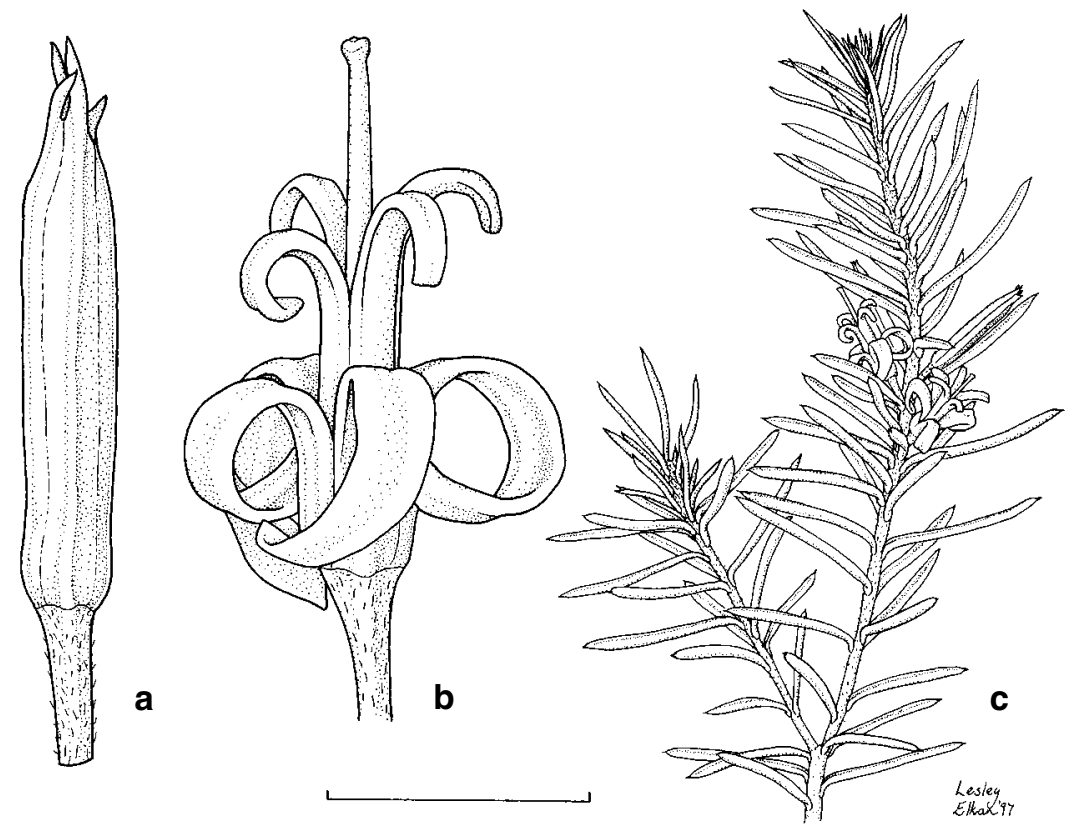

Fig. 1. Persoonia hindii. a, flower bud; b, flower; c, habit (from Weston 1948 \& Godden). Scale bar: $\mathrm{a}, \mathrm{b}=6 \mathrm{~mm} ; \mathrm{c}=30 \mathrm{~mm}$. 

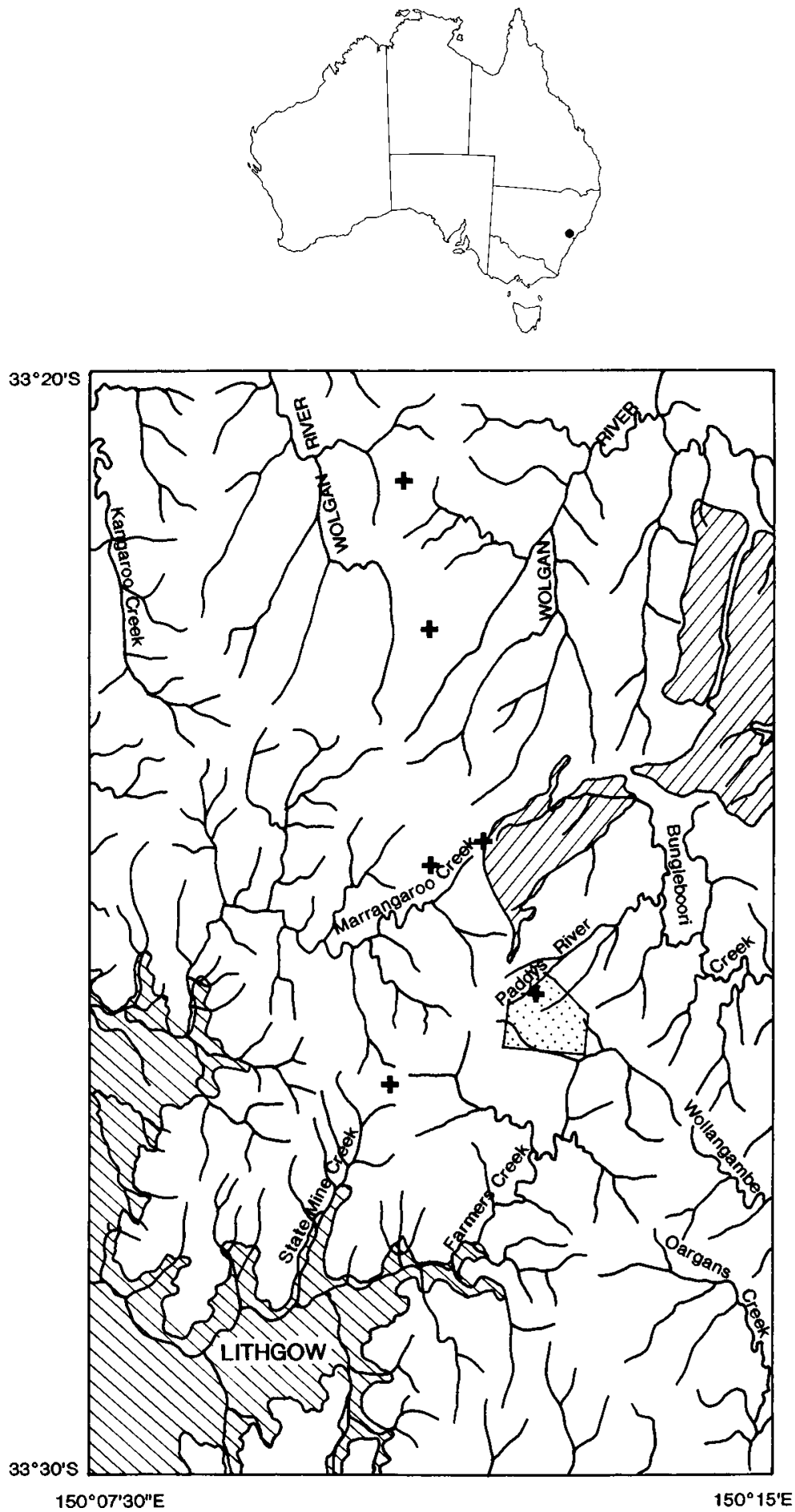

Fig. 2 (top). Distribution of Persoonia hindii $(\bullet)$ shown on a map of Australia. Fig. 3 (above). Distribution of Persoonia hindii (+) shown on a 1:100,000 map of the south-western part of Newnes State Forest; land cleared for agricultural and urban development $(\backslash \backslash \backslash)$, Pinus radiata plantations $(/ / /)$; freehold land including sand mine (: : :) . 
Proposed conservation status: geographically restricted, vulnerable, not conserved (2V coding of Briggs \& Leigh 1996). Sand mining, forestry, and fire are the most obvious potentially threatening processes that could endanger this species. The distribution of $P$. hindii is entirely enclosed by the boundaries Newnes State Forest, although one population occurs on a block of excised freehold land, used for sand mining. Expansion of the mine into the area occupied by this population would destroy it. The stoloniferous, suckering habit of $P$. hindii indicates that it is probably fire-resistant and possibly robust to other forms of disturbance that would accompany forestry operations. A more detailed survey of the distribution of $P$. hindii is needed to inform planning in Newnes State Forest.

Notes: P. hindii belongs to a small group of south-eastern Australian species, which is characterised by narrow leaves that become concave on drying. The other members of this group are P. chamaepeuce Lhotsky ex Meisn., P. juniperina Labill., P. virgata R. Br., $P$. tenuifolia R. Br., and P. acerosa Sieber ex Schult. \& Schult. f. It is most easily distinguished from all of these species by its flower buds, which appear square in cross-section due to the strongly keeled tepal midribs and which show a contrast between the moderately hairy pedicels and the glabrous perianth. It most closely resembles $P$. chamaepeuce, with which it shares its stoloniferous, suckering habit, a feature that is potentially a synapomorphy grouping them as sister species (sensu Hennig 1966). Its leaves are much fleshier when living than those of P. chamaepeuce, and much more rigid and deeply concave when dried.

$P$. hindii grows on sandstone, a substrate on which $P$. chamaepeuce has not been collected in New South Wales (although there is a record of P. chamaepeuce from the Grampians in western Victoria, presumably on sandstone). In New South Wales, $P$. chamaepeuce occurs on granites and metasediments both north and south of the Sydney region.

The distribution of $P$. hindii is extremely patchy, being known from only six small populations, each no more than $100 \mathrm{~m}$ wide. Given its stoloniferous habit and its presumed fire-tolerance, it is possible that each "population" could consist of a single clone. At least some plants are known to set fruit, so the rate of seedling recruitment would have to be extremely low for such a population structure to be maintained. Nevertheless, this would not be very surprising: seedling recruitment has been found to be almost non-existent in another fire-tolerant species, Persoonia elliptica (Abbott \& Van Heurck 1988).

Selected specimens (11 collections examined): New South Wales: Central Tablelands: Sunnyside Road, $2.4 \mathrm{~km}$ from Birds Rock Trail, 3321'01"S 150¹0'58"E, A.J. Whalen 32, P.D. Hind \& J. Cornford, 26 Mar 1993 (BRI, CANB, HO, MEL, NSW); $2.1 \mathrm{~km} \mathrm{~W}$ along Sunnyside Road from Blackfellows Hand Road junction, 3322'21"S 150'11'13"E, P.D. Hind 6497 \& C. Daniels, 17 Feb 1992 (CANB, NSW); Bungleboori picnic area, across road from cleared, grassy area, 33 $24^{\prime} 30^{\prime \prime S} 150^{\circ} 12^{\prime} 20^{\prime \prime} \mathrm{E}$, P.H. Weston 1949 \& D.C. Godden, 24 Jan 1996 (NSW); $1 \mathrm{~km} \mathrm{SW}$ of Bungleboori picnic area along trail to the 'Snow Gum Reserve' (Lithgow water supply), 3324"S 150'10'E, P.D. Hind 6507, P. Kodela \& S. Goodwin, 22 Mar 1992 (NSW); Bungleboori-Lithgow road, at headwaters of State Mine Creek, 3326'29"S 150¹0'51"E, P.H. Weston 1952 \& D.C. Godden, 24 Jan 1996 (NSW).

\section{Amendments to published keys to Persoonia}

The keys published by Weston $(1991,1995)$ need to be altered to accommodate $P$. hindii, but in both cases this is an awkward task. With both keys, specimens of $P$. hindii key out either to P. juniperina (group 1, couplet 1 in Weston 1991; couplet 50 in Weston 1995) or to a couplet asking whether the pedicels AND tepals are glabrous or hairy (group 1, couplet 10 in Weston 1991; couplet 59 in Weston 1995 - P. hindii has 
hairy pedicels and glabrous tepals, thus fitting neither alternative). The easiest way to modify these keys is to modify one existing couplet and to insert two new ones.

The first new couplet distinguishes $P$. hindii from $P$. juniperina as follows:

A Tepals hairy on abaxial surface, 6-11 mm long; leaves not succulent when living

P. juniperina

$\mathrm{A}^{*}$ Tepals glabrous on abaxial surface, $12-15 \mathrm{~mm}$ long; leaves succulent when living

P. hindii

Group 1, lead 10 (Weston 1991) and lead 59 (Weston 1995) are modified as follows:

B Pedicels glabrous

$\mathrm{B}^{*}$ Pedicels hairy

The following new couplet is inserted before group 1, couplet 15 in Weston (1991) and before couplet 65 in Weston (1995):

C Tepals glabrous, strongly keeled along the abaxial midrib so that the buds appear square in cross-section; leaves succulent when living, smooth when mature

P. hindii

$C^{*}$ Tepals sparsely to moderately hairy, the buds not usually appearing square in cross-section; leaves either not succulent when living or, if succulent, then strongly papillose-scabrous when mature.

\section{Acknowledgments}

Peter Hind collected material especially for this study and provided useful field observations. Rob Smith (State Forests of New South Wales) provided information on the boundaries of the sand mine in Newnes State Forest. Dianne Godden assisted in the field. Lesley Elkan drew the figures. Barbara Wiecek and Rob Smith provided helpful comments on earlier drafts of the manuscript.

\section{References}

Abbott, I. \& Van Heurck, P. (1988) Widespread regeneration failure of Persoonia elliptica (Proteaceae) in the northern Jarrah forest of Western Australia. J. Roy. Soc. Western Australia 71: 15-22.

Benson, D.H. \& Keith, D.A. (1990) The natural vegetation of the Wallerawang 1:100,000 map sheet. Cunninghamia 2: 305-335.

Briggs, J.D. \& Leigh, J.H. (1996) Rare or Threatened Australian Plants, 1995 revised edition (CSIRO: Collingwood).

Hennig, W. (1966) Phylogenetic Systematics. (University of Illinois Press: Urbana).

Weston, P.H. (1991) Persoonia. Pp. 4-19 in G.J. Harden (ed.), Flora of New South Wales, vol. 2 (New South Wales Univ. Press: Kensington).

Weston, P.H. (1994) The Western Australian species of Persooniinae (Proteaceae). Telopea 6: 51-165. Weston, P.H. (1995) Persoonia. Flora of Australia 16: 50-125.

Manuscript received 7 May 1997

Manuscript accepted 17 September 1997 
